\title{
New farm Acts, 2020: rationale and challenges
}

\author{
S. K. Srivastava* and Raka Saxena
}

The recent development agenda in agriculture aims towards making the sector remunerative, competitive and sustainable through accelerating ongoing transformation and addressing the emerging challenges. The enactment of new farm Acts, 2020 has led to an intense debate with arguments both in favour and against their likely implications on farmers' welfare and the agricultural sector. This article evidently examines the rationality of enacting new farm Acts, and discusses critical issues for their effective implementation and realizing the intended benefits. These Acts aim to create an ecosystem for efficient and competitive marketing and foster investment in post-production stages. Realization of intended benefits requires strengthening of aggregating institutions like farmer producer organizations, creating enabling conditions for competition between Agricultural Produce Marketing Committee (APMC) mandis and outside trade, and developing an effective market intelligence and price information system for efficient price discovery outside APMCs.

Keywords: Agriculture, challenges, critical issues, Farm Acts.

BESIDES sustaining food and nutritional security, agriculture plays a critical role in the overall economic development of our nation. The technological interventions and policy reforms initiated during 1960s have successfully transformed India from a food-deficit economy to a food-surplus nation at aggregate level and led agriculture on the path of commercialization. However, discrimination existed between agriculture and non-agriculture evidenced through the disparity in per worker income in the agriculture and non-agriculture sectors-per worker income in the non-agriculture sector has reportedly increased at a much faster rate than per worker income in agriculture $^{1,2}$. Considering this, the development agenda in agriculture has shifted from production enhancing strategies to income improvement strategies for farmers' welfare. The strategies for doubling farmers' incomes accord due emphasis on realization of remunerative prices by the farmers through appropriate marketing interventions and reforms ${ }^{3}$. Further, agriculture is accorded as a priority sector for meeting commitments like becoming a USD five trillion economy by 2024-25 and achieving the Sustainable Development Goals (SDGs) by 2030. For improving farmers' income and realizing other commitments, the agriculture sector needs to become more remunerative, competitive and sustainable. This requires acceleration in ongoing transformation in agriculture, and unleashing the potential by effectively addressing the emerging challenges through technological and policy reforms in the sector.

\footnotetext{
S. K. Srivastava and Raka Saxena are in the ICAR-National Institute of Agricultural Economics and Policy Research, New Delhi 110 012, India.

*For correspondence. (e-mail: shivendraiari@gmail.com)
}

In September 2020, the Union Government enacted two new farm Acts [Farmers' Produce Trade and Commerce (Promotion and Facilitation) Act, 2020 (ref. 4) and Farmers' Empowerment and Protection Agreement on Price Assurance and Farm Services Act, 2020 (ref. 5)] for agriculture and amended the Essential Commodities Act, 1951 (ref. 6) for foodstuff to provide an enabling environment for accelerating agricultural development in the country. These new Acts, however, are being widely debated on their implications for farmers' welfare and the agriculture sector. There are various arguments both in favour and against the likely benefits of these Acts on the farm economy. It is essential that any argument, either in favour or against, should be based on empirical evidences rather the ideological perceptions and beliefs. This article analyses evidences on the status of food production and farmers' income, and critically examines the rationality of enacting these Acts. Further, critical issues for realizing the intended benefits of the Acts are discussed. The article first provides evidences on the status of agriculture and farmers' income, and flags the emerging challenges in the sector. Subsequently, the new farm Acts are briefly explained and their rationality to address the emerging challenges is examined. Finally, it discusses the critical issues for effective implementation of the new Acts and realizing the intended benefits.

\section{Agriculture: emerging challenges}

\section{Food production and stability in agriculture}

With the increasing population and changing food habits, level and composition of food demand is changing over 
Table 1. Food production trend in India

\begin{tabular}{lccc}
\hline Year & $\begin{array}{c}\text { Food production* } \\
\text { (million tonnes) }\end{array}$ & $\begin{array}{c}\text { Population } \\
\text { (million) }\end{array}$ & $\begin{array}{c}\text { Per capita food production } \\
\text { (kg/capita/day) }\end{array}$ \\
\hline $1950-51$ & 125 & 359 & 0.95 \\
$1960-61$ & 178 & 434 & 1.12 \\
$1970-71$ & 247 & 541 & 1.25 \\
$1980-81$ & 311 & 679 & 1.25 \\
$1990-91$ & 462 & 839 & 1.51 \\
$2000-01$ & 622 & 1,019 & 1.67 \\
$2010-11$ & 891 & 1,186 & 2.06 \\
$2018-19$ & 1,230 & 1,327 & 2.54 \\
\hline
\end{tabular}

*Foodgrains, edible oil, sugar, fruits and vegetables, spices, milk, eggs, meat and fish aggregated using foodgrain equivalent unit prices as weight.

time. Agriculture bears a prime responsibility of producing adequate amounts of required food to meet the demand in the country. During 1950s and 1960s, India was deficient in food with per capita production of about $1 \mathrm{~kg} /$ day (Table 1). The technology and policy-led Green Revolution initiated during late 1960s resulted in higher growth in food production compared to the population and ushered India into a food-surplus nation. By 2018 19 , the total and per capita aggregate food production increased to 1230 million tonnes and $2.54 \mathrm{~kg}$ /day respectively. The present level of food production is sufficient to sustain food security in the country ${ }^{7}$.

However, evidence reveals a mismatch between demand and supply of food commodities at disaggregate level ${ }^{8}$. The country is witnessing accumulation of surplus stock of commodities like rice and sugar. On the other hand, huge quantities of pulses and edible oil are imported to meet the domestic demand. Even the import of fresh fruits, which can be grown in the country, is rising. The changing consumption pattern away from staple to high-value food commodities warrants the production basket to be responsive to the shifting food demand ${ }^{9}$.

Productivity has emerged as a major contributor of the rising food production. Chand and Srivastava ${ }^{10}$ found that $92 \%, 76 \%$ and $67 \%$ of the growth in production of cereals, pulses and oilseeds between 2004-05 and 2014-15 was attributed to increase in yield respectively. With the improving infrastructure and technological adoption, agricultural productivity is rising with improved stability in output. The estimated instability index of gross value added (at 2011-12 prices) of agriculture was 2.75 for the period 2010-11 to 2018-19 compared to 4.67 during 2000-01 to 2010-11. However, the average level of productivity in the country is still far less than the world average, and there exists a wide yield gap along with large variation in productivity across the states. Amidst shrinking land and water resources, productivity must be improved through acceleration in conducive infrastructure and technological adoption to produce sufficient food for the growing population and create tradable surplus.

\section{Commercialization of agriculture}

Evidence from both factor and product side indicates that Indian agriculture is gradually transitioning from subsistence to commercialization with rising dependence on market for input needs and output disposal (Table 2). Rising commercialization from the product side is indicated through increasing marketed surplus, increasing agricultural exports and diversification towards non-foodgrains crops. On the factor side, rising commercialization is reflected from the increasing use of quality seeds and fertilizer consumption, improvement in irrigation coverage and electricity use, and reduction in labour use due to rising farm mechanization and other developmental factors.

Seed is the most critical input for crop production and use of quality seed alone can increase productivity by 15 $20 \%$ (ref. 11). Although the use of quality seeds is increasing, $60-65 \%$ of the seeds in use are either farmsaved or unlabelled ${ }^{11}$. There exists a huge scope to improve the value chain by improving seed infrastructure and strengthening partnership with the private sector. The use of fertilizers has played a catalytic role in enhancing agricultural productivity and output. However, its use has remained unbalanced and inefficient, resulting in negative consequences on soil fertility, environment and farm economics. It is necessary to improve the infrastructure of soil testing laboratories and the quality of customized fertilizers, and create awareness among the farmers regarding balanced and efficient use of fertilizers. Despite significant improvement in the irrigation infrastructure, more than half of agricultural lands is rainfed and irrigation water-use efficiency is sub-optimal. The level of farm mechanization is increasing, but its pace is inadequate to absorb the wage-push cost inflation ${ }^{12}$. Therefore, the share of labour in the cost of cultivation is rising despite declining physical use of labour in agriculture. This warrants accelerating pace of farm mechanization through developing suitable farm machinery and enhancing its economic access through promoting institutional innovations like custom-hiring centres. These evidences 
Table 2. Indicators of commercialization of Indian agriculture

\begin{tabular}{|c|c|c|c|c|}
\hline Indicators & TE $1987-88$ & TE $1997-98$ & TE $2007-08$ & TE $2017-18$ \\
\hline \multicolumn{5}{|l|}{ Factor side } \\
\hline Certified seeds (lakh quintals) & 56 & 74 & 154 & 335 \\
\hline NPK (kg/ha GCA) & 49 & 78 & 111 & 127 \\
\hline Irrigation coverage $(\%)$ & 32 & 39 & 45 & 48 \\
\hline Electricity use (kWh/ha) & 168 & 460 & 506 & 947 \\
\hline Labour use (h/ha) & 674 & 663 & 673 & 566 \\
\hline \multicolumn{5}{|l|}{ Product side } \\
\hline Marketed surplus ratio** $(\%)$ & - & - & 68 & $78^{\#}$ \\
\hline Share of export in agricultural output (\%) & 3.3 & 5.8 & 6.9 & 7.8 \\
\hline Area share of non-foodgrains in GCA $(\%)$ & 31 & 33 & 35 & $37 *$ \\
\hline Value share of non-foodgrains in crop output $(\%)$ & 58 & 60 & 64 & 66 \\
\hline
\end{tabular}

*Triennium ending (TE) 2016-17; ${ }^{\#}$ TE 2014-15.

**Average over crops, namely rice, wheat, maize, jowar, bajra, barley, ragi, arhar, gram, urad, moong and lentil.

from the factor side reveal the scope to accelerate technological adoption and institutional innovations in accessing modern inputs and farm services.

The rising commercialization from the product side is evident from the increasing marketed surplus. After meeting the household and farm needs, a substantial portion of the output is disposed in the market by the farmers. The existing market infrastructure, however, is inadequate to effectively absorb and efficiently monetize the farm output leading to seasonal and regional variations in demand-supply balance ${ }^{3}$. Export is emerging as an important alternative avenue to dispose the surplus agricultural output. Although the share of export in agricultural output is increasing, its level is low at $7.8 \%$ (Table 2). According to the emerging scenario of demand and supply, India will have to sell $20-25 \%$ of its incremental agri-food production in the overseas markets in the coming years ${ }^{13}$. This warrants enhancing competiveness of agricultural commodities in the international market through strengthening the value chain and producing quality products according to the trade standards. Diversification away from staple food is an important indicator of the increasing commercialization of agriculture. The rising share of non-foodgrains in gross cropped area and crop output over time indicates increasing diversification towards high-value crops. Notwithstanding, non-foodgrains cover only $37 \%$ of gross cropped area but contribute $66 \%$ to crop output. Low coverage and significantly higher productivity of non-foodgrains compared to staple crops indicate an immense potential to improve farmers' income by accelerating diversification in the country.

\section{Income of farm households}

Despite increasing production and rising commercialization of agriculture, income of the farmers is at a low level in the country. Estimates from the 2018-19 Periodic Labour Force Survey (PLFS) of the National Sample Survey Office (NSSO) indicate that a cultivator earns
Rs 8241 per month from agriculture compared to Rs 11,217 by a worker engaged in non-agricultural activities in rural areas. Low income of the farmers is also reflected by the higher incidence of poverty among farmer households (22\% in 2011-12) compared to non-agricultural households $(16 \%)$. Further, low level of farmers' income coexists with wide inter-state disparity. Farmers in Punjab and Haryana earn up to three times higher income compared to those in Jharkhand, Odisha and Chhattisgarh (Figure 1). Chand et al. ${ }^{2}$ reported that the disparity in income of a cultivator and a non-agricultural worker increased from $1: 3$ to $1: 4$ between 1983-84 and 200405 , which declined to $1: 3.15$ and a non-agricultural worker earned 3.15 times the income of a cultivator in 2011-12. The recent employment surveys (2011 and 2017-18) by NSSO indicate continuous reliance on agriculture by the farmers (workers as self-employed in agriculture), while majority of labour has shifted to non-farm occupations $^{14}$. Farmers constituted about one-third of the total workforce (usual status) in 2017-18, which accentuates the need to increase their income for equitable economic development.

The existing strategies of agricultural development explicitly recognize increasing farmers' income in addition to the output growth. A target has been fixed to double farmers' income by 2022-23 from the base year 2015-16. Seven sources of growth have been identified and examined in terms of major contribution towards income growth. Among others, low price realization and slow pace of diversification are the two major reasons for low level of farmers' income in the country.

Figure 2 presents evidences from the Cost of Cultivation Survey (CCS) of the Directorate of Economics and Statistics (DES) on production cost and price realized by paddy farmers in 2016-17. The prevailing prices of the widely grown paddy crop covered cost $A_{2}$ plus imputed value of family labour ( $\cos t \mathrm{~A}_{2}+\mathrm{FL}$ ) for more than $90 \%$ of the farmers in 2016-17. However, the prices realized by the farmers were only about $15 \%$ higher than cost 


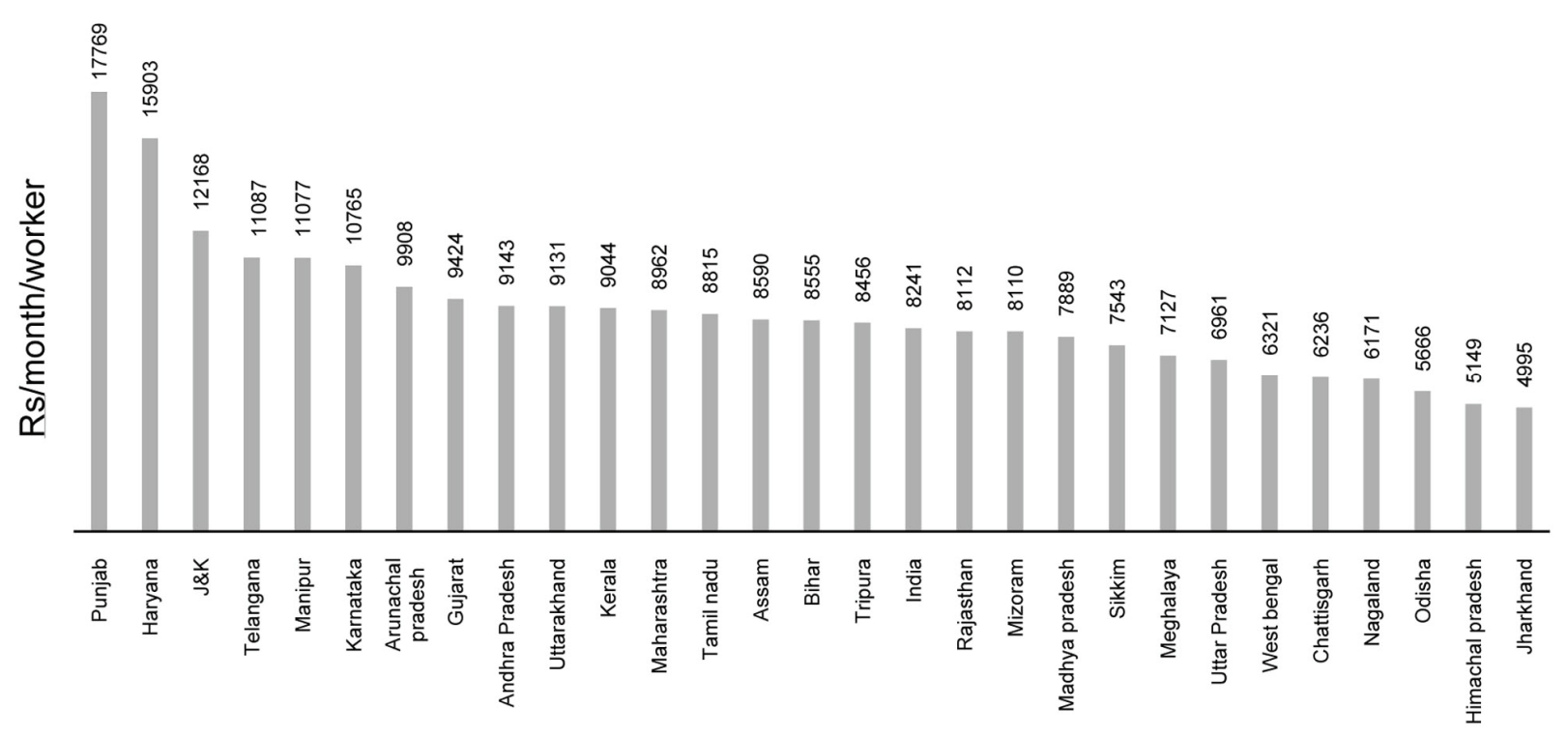

Figure 1. State-wise gross earnings per worker from agriculture in 2018-19.

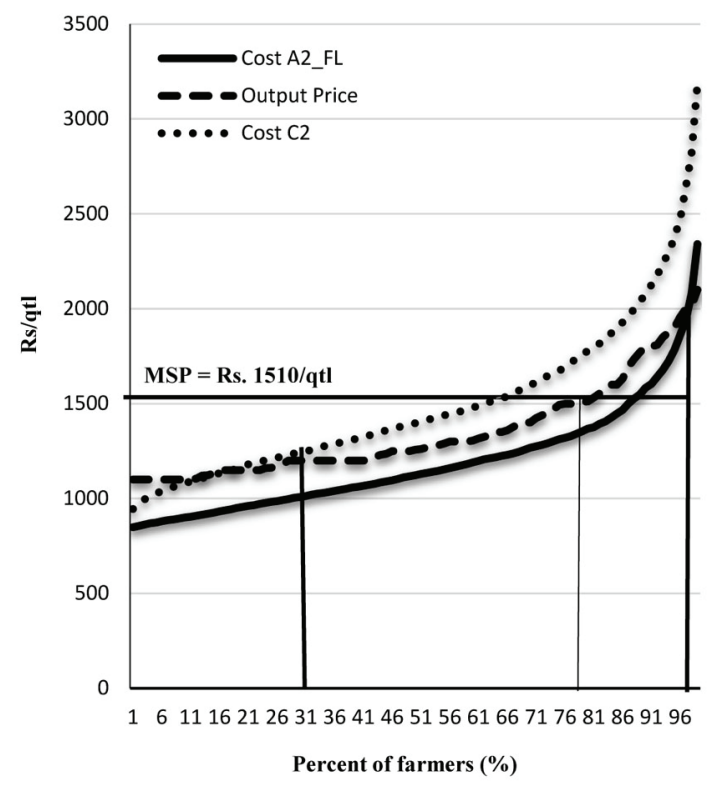

Figure 2. Production cost incurred and price realized by farmers in paddy, 2016-17.

$\mathrm{A}_{2}+\mathrm{FL}$ compared to the recommended level of at least $50 \%$. Approximately, $22 \%$ of farmers realized the minimum support price (MSP) for paddy. Further, about 60$70 \%$ of farmers in the country realized lower prices than $\operatorname{cost} \mathrm{C}_{2}$. These evidences reveal that prices realized by the farmers do not cover total production cost in several cases and are not remunerative.

The major reasons of poor price realization are lack of bargaining power of the farmers on account of low volume of marketable surplus and poor market access. The latest Situation Assessment Survey of NSSO (201213) reveals that marginal and small farmers, who consti- tute $86 \%$ of the total farmers, dispose up to $75 \%$ of their produce (in aggregated value terms) outside the Agricultural Produce Marketing Committee (APMC) mandis. In order to sell their produce to mandis, they need to travel at least $20-25 \mathrm{~km}$ and low tradable volume makes it unviable. Therefore, they are forced to sell through local traders who act as aggregators and face no competition because of trade restrictions outside the APMCs. In most cases, first transaction between farmers and traders is inter-locked in nature, either due to lack of scale or indebtedness of the farmers to the local traders.

Another reason of low farmers' income is the slow pace of diversification. In Triennium Ending (TE) 201819 , the agricultural production basket was dominated by the crop sub-sector (56\% of agricultural output) followed by livestock (31\%), forestry and logging (7\%), and fisheries and aquaculture $(6 \%)$. Further, within the crop subsector, $63 \%$ of the gross cropped area was covered by foodgrains which contributed only $33 \%$ to the total crop output. Although cultivating non-foodgrains is twice as productive, farmers are not able to diversify due to high capital requirements, poor market availability, inadequate storage and processing infrastructure and high price risk.

High-value commodities are comparatively more perishable, and require proper storage and processing facilities to avoid post-harvest losses and glut in the harvest season. According to the report ${ }^{3}$, current dry warehousing capacity in the country is 184 million tonnes, which is less than the estimated requirement. Further, it is required to upgrade the existing godowns and warehouses to make them WDRA (Warehouse Development Regulation Authority) compliant. Similarly, transport agri-logistics and processing infrastructure is grossly inadequate to add sufficient form and form utility to the agricultural produce. Overall, value addition for the total 
food produced in India is estimated to be just about $10 \%$ (varying from $4 \%$ in fresh agro-produce to $50 \%$ in milk) compared to about $65 \%$ in developed countries like USA and $23 \%$ in developing countries like China. Inadequate post-harvest agri-logistics and processing facilities lead to huge losses (about Rs 92,000 crores in 2013 according to the estimates of ICAR-Central Institute of PostHarvest Engineering and Technology, Ludhiana) and high price variability. It is estimated that wholesale prices of fruits and vegetables are up to seven times more volatile compared to cereals, which discourages farmers to diversify and earn higher income (Figure 3). Improving agri-logistics and processing infrastructure, and linking farmers to processors, are therefore necessary to accelerate diversification towards high-value food commodities. As the food processing industry is much more labourintensive compared to other industries ${ }^{15}$, promoting food processing in rural areas would also generate employment and help in shift of workforce from primary agriculture to industry. Improving post-harvest infrastructure requires fostering public and private investment.

Investment in productive assets is a prerequisite for accelerating growth in any sector. The gross fixed capital formation (GFCF) in agriculture was $13.2 \%$ of its output in 2017-18, 76\% of which was contributed by households. Evidences from the latest All India Debt and Investment Survey (2012-13) of NSSO reveal that small and marginal farmers, who operate $47 \%$ of agricultural land, constitute only $9 \%$ in the total investment by households. Thus, on per hectare basis, marginal and small farmers invest up to five times less on agriculture compared to the medium and large farmers. Further, during 2010-11 to 2017-18, investment in agriculture remained stagnant despite about $6 \%$ growth in public investment in agriculture. This was due to negative growth $(-0.77 \%)$ in investment by the farmers. Low earnings from agriculture do not generate sufficient savings which can be invested

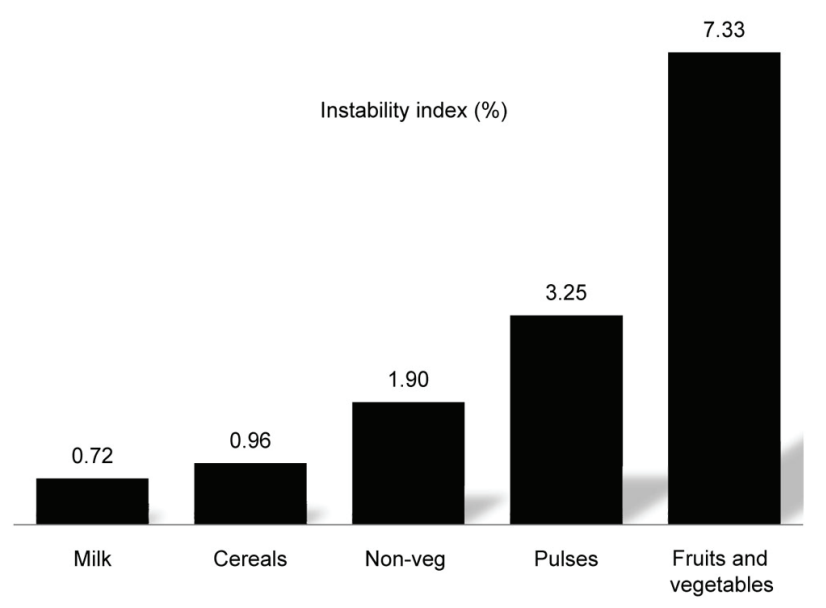

Figure 3. Instability index of wholesale prices during April 2011 to November 2020. in productive assets and farmers remain in a vicious cycle in low income-low investment-low income. The focus of the Government towards improving farmers' income is expected to break this vicious cycle. One measure to do so is fostering corporate investment, which at present is only $2 \%$ of the total investment in agriculture. The challenges emanating in the current agri-business environment heighten the need for strong backward and forward linkages to facilitate optimal input use and effective monetization of agricultural output. This requires creation of conducive business environment and support through developmental initiatives, technological dissemination and favourable policies.

\section{New Farm Acts, 2020}

Considering the above challenges and pursuing the agenda of doubling farmers' income, the Union Government enacted the Farmers' Produce Trade and Commerce (Promotion and Facilitation; FPTC) Act, 2020, Farmers' Empowerment and Protection Agreement on Price Assurance and Farm Services Act, 2020 and Essential Commodities (Amendment) Act, 2020 in September 2020. These legislative measures aim to provide an ecosystem for efficient marketing, improve infrastructure and strengthen the value chain of agricultural commodities.

\section{Farmers' Produce Trade and Commerce (Promotion and Facilitation) Act, 2020}

The FPTC Act provides the farmers and traders freedom of choice of sale and purchase of farmers' produce at any place within or outside APMC mandis ${ }^{4}$. The Act also provides a facilitative framework for setting up of electronic trading platform and promote efficient, transparent, competitive, barrier-free inter-state and intra-state trade and commerce of farmers' produce outside physical premises of APMC mandis. The Act is not intended to replace the State APMC Act, but to provide farmers with additional marketing channels to existing APMCs. It also has a provision to prescribe modalities for the registration of traders and trade transactions in the trade area and allows the Government to regulate the system, if required. No market fee or cess or levy under the State APMC Act shall be levied on any farmer or trader or electronic trading platform for trade outside APMC mandis.

Numerous studies and surveys, including those by the NSSO reveal that large volume of trade takes place outside APMC mandis, which is mostly unregulated and a non-competitive trading environment. Legalizing such transactions without provision of market fee is expected to incentivize organized buyers and entities to directly purchase from the farm gate or aggregate point. This would ensure improved marketing efficiency through increased competition among the buyers, improve 
bargaining power of the farmers and facilitate realization of remunerative prices. Thus, successful implementation of the Act has the potential to improve the commodity supply chains and value chains for effective outcomes. The APMCs will be required to improve their efficiencies and services to attract trade through them. This will create new marketing platforms and will ease the marketing of agricultural produce. In the long run, coexistence of both APMCs and multiple channels outside APMCs would make agricultural marketing more competitive, efficient and liberalized.

\section{Farmers (Empowerment and Protection) Agreement on Price Assurance and Farm Services Act, 2020}

This Act provides a legal framework for agreement between farmers and sponsors for purchase of farming produce and provision of farm services entered into before harvest ${ }^{5}$. Considering the issues and limitations to enhance the resource use efficiency and optimal input use pattern, primary processing to reduce the losses and enhancing agricultural exports, the Act protects and empowers farmers to engage with agri-business firms, processors, wholesalers, exporters or large retailers for farm services. Both parties entering into the agreement deem to comply with mutually agreed quality grade and standards of farming produce at pre-agreed guaranteed prices explicitly mentioned in the agreement. The sponsor is responsible for timely acceptance of the delivery of produce at the farm gate. The sponsor is prohibited from acquiring ownership rights or making permanent modification on the farmer's land. The agreement may be linked with the insurance or credit instruments to ensure risk mitigation and flow of credit to the farmer or sponsor, or both. The produce out of the agreement covered under this Act shall be exempted from any control orders or obligations related to stock limits under the Essential Commodities Act, 1951. The parties entered into the agreement may, with mutual consent, alter or terminate such agreement for any reasonable cause. In case the sponsor fails to comply with the agreed terms, there is a provision for penalty extending to one and half times the amount owed. If a farmer breaches the agreement, the recovery shall not exceed the actual cost incurred by the sponsor on account of any advance payment or cost of input supplied by him. In case default by the farmer is due to force majeure, then no order for recovery of the amount shall be passed against him. Any recovery of amount due to the farmer may be obtained as arrears of land revenue and no action shall be initiated for recovery of dues against the agricultural land of the farmers.

The above provisions of the Act are mostly in favour of the farmers and have the potential to incentivize them to diversify towards high-value crops by reducing market and price risk. The Act also provides an enabling envi- ronment for the processors and exporters to secure raw material of a pre-specified quality. This in turn would strengthen the linkages between producers and processors/exporters. The provision of supplying farm inputs and services to the farmers will increase the adoption of modern technologies and good agricultural practices for producing quality products demanded by the consumers. Overall, the Act creates an ecosystem to strengthen the supply chain, modernize agriculture and make agriculture sector more responsive to the market forces.

\section{Essential Commodities (Amendment) Act, 2020}

The Essential Commodities Act (ECA), 1951 has been modified for agriculture and food commodities, including cereals, pulses, potato, onion, edible oilseeds and oils ${ }^{6}$. Under the modified Act, the Government may regulate the supply of these commodities only under extraordinary circumstances (war, famine, extraordinary price rise and natural calamities) based on a transparent criterion. The specified criterion for invoking ECA in the situation of price rise is $100 \%$ increase in the retail price of horticulture produce or $50 \%$ increase in that of non-perishable agri-food stuff over the price prevailing in the preceding 12 months or average price of the last five years, which ever is lower. This modification provides a predictability in invoking the ECA by the Government. Onion has been the most volatile commodity during the recent decade. The Centre imposed limits on the extent of onion stocks held by the traders and wholesalers during October 2020, invoking the provision under the newly amended ECA. The amended ECA included that stock holding limits can be imposed only in extraordinary circumstances like droughts, floods, natural calamities or exceptional spike in prices. An exceptional increase was noted in the onion prices, considering which the stocking limits were imposed to prevent and control the price spikes.

To prevent crop loss and wastage, the processors need to be incentivized in terms of suitable policies and logistics. The commodity value chains need to tap the inherent potential through trade activities. The Act includes that regulating stock limit shall not apply to a processor or value chain participant of any agricultural produce, if the stock limit of such a person does not exceed the overall ceiling of installed capacity of processing, or the demand for export in case of an exporter. Given the surplus food production amidst the huge inadequacy of storage and other logistics infrastructure, modified ECA incentivizes private players to invest in such infrastructure. Improved storage infrastructure would reduce distress sale by the farmers, price crash during harvest season due to glut and post-harvest losses. Better inventory management will also help in accelerating processing and export of farm produce. Overall, the Act provides a favourable environment for fostering the much needed private investment in 
post-harvest infrastructure and improving food management in the country.

\section{Critical issues for implementing the new Acts}

Successful implementation of the new Acts is expected to address key challenges in making Indian agriculture more remunerative and competitive. However, successful implementation and realization of intended benefits depend on few critical issues. Although the FPTC Act provides legal freedom to the buyers to directly procure farm produce from the farmers, reaching widely spread farmers with small land holding and small volume is a challenging task, both economically and physically. A situation may arise when large companies, in order to economize logistics cost, may engage with middlemen instead of directly purchasing from the farmers. If this happens, it may restrict benefits of the new marketing system to the intended beneficiaries (i.e. farmers). Thus, the aggregator assumes a critical role in the success of the FPTC. In order to ensure maximum benefits to the farmers (rather the aggregator/ middlemen), it is essential to strengthen the institutions such as Farmer Producer Organizations (FPO), cooperatives, etc. and develop their linkages with the organized buyers.

Secondly, the FPTC Act aims to create competitive conditions in the market and improve bargaining power of the farmers. This will happen when APMC mandis and trade channels outside the mandis coexist and compete with each other. It would require a level playing field and nurturing of APMCs till they become more competitive and efficient. More investment from the Government shall be infused for improving infrastructure and services in the APMC mandis. The recent announcements in the Union Budget 2021 are aligned with the new reforms. To develop the APMCs, the Government announced utilization of agri-infrastructure fund for infrastructure development, which will augment infrastructure facilities in the APMCs. Also, 1000 more markets will be linked with National Agriculture Market (e-NAM). Further, for efficient price discovery outside the APMC mandis and a check on exploitation of the farmers, it is essential to have an effective market intelligence and price information system. This requires creating an information technology-enabled innovative system to track transactions outside the mandis. Notwithstanding, the FPTC Act provides provisions to develop such a system so as to enable the Government to regulate trade in case it is not working properly. Such a supporting infrastructure and system shall be accorded high priority.

\section{Conclusion}

India has successfully transformed from a food-deficit to a food-surplus nation due to technological and policy reforms in agriculture initiated during the 1960s. The development agenda at the national level has shifted from food production to food management and improvement in farmers' income. Agriculture has also been accorded high priority in meeting the commitments such as becoming a USD 5 trillion economy (by 2024-25) and achieving SDGs (by 2030). At the same time, the sector suffers from a number of challenges on product and factor fronts, which need to be tackled through strengthening of backward and forward linkages. Although production is growing steadily, the level of productivity is still low with wide variation across states. Similarly, evidences point out rising commercialization of agriculture, but at a slow pace due to various infrastructural, institutional and policy bottlenecks. Consequently, farmers' income remains at low level with wide regional variations. Low price realization and slow pace of diversification are the two major reasons for low level of farmers' income in the country among few important sources. Meeting such targets and handling these challenges warrants agriculture to become more remunerative, competitive and sustainable by addressing the emerging challenges through technological innovations and policy reforms.

In view of these opportunities and hindrances, the Government has enacted two new farm Acts and modified ECA, 1951. The FPTC Act, 2020 aims to create an ecosystem for promoting efficient, transparent, competitive, barrier free inter-state and intra-state trade of farmers' produce outside the APMCs. This is expected to improve market access and price realization by the farmers. The Farmers (Empowerment and Protection) Agreement on Price Assurance and Farm Services Act, 2020 provides a legal framework of agreement between farmers and sponsors and is expected to reduce market and price risk, accelerate diversification and strengthen linkages between farmers and processors/exporters. The Essential Commodities (Amendment) Act, 2020 provides predictability in Government action to invoke ECA and is expected to foster private investment in storage and logistics infrastructure. A number of provisions have already been made in the Union Budget 2021 to align these priorities with the national agenda. However, realization of intended benefits from these Acts requires strengthening of aggregating institutions like FPOs, creating enabling conditions for competition between APMC mandis and outside trade, and developing an effective market intelligence and price information system for efficient price discovery outside the APMCs.

Disclaimer: The views expressed here are the authors' own and do not represent the official position of the institution to which they belong.

Conflict of interest: none.

1. Chand, R., The state of Indian agriculture and prospects for future. In Growth, Equity, Environment and Population: Economic and 
Sociological Perspectives (eds Chopra, K. and Rao, C. H. H.), Sage, New Delhi, 2008, pp. 133-148.

2. Chand, R., Saxena, R. and Rana, S., Estimates and analysis of farm income in India, 1983-84 to 2011-12. Econ. Polit. Wkly, 2015, 50(22), 139-145.

3. GoI, Report of the Committee on Doubling Farmers' Income: post production agri-logistics: maximizing gains for farmers, volume III. Department of Agriculture, Cooperation and Farmers' Welfare, Ministry of Agriculture and Farmers' Welfare, Government of India, 2017; http://agricoop.gov.in/sites/default/files/DFI\%20Volume\%203.pdf

4. GoI, The Farmers' Produce Trade and Commerce (Promotion and Facilitation) Act, 2020, The Gazette of India, CG-DL-E-27092020222039. Ministry of Law and Justice, Government of India, 2020.

5. GoI, The Farmers (Empowerment and Protection) Agreement on Price Assurance and Farm Services Act, 2020. The Gazette of India, CG-DL-E-27092020-222040, Ministry of Law and Justice, Government of India, 2020.

6. GoI, The Essential Commodities (Amendment) Act, 2020. The Gazette of India, CG-DL-E-27092020-222038, Ministry of Law and Justice, Government of India, 2020.

7. GoI, Demand and supply projections towards 2033: crops, livestock, fisheries and agricultural inputs. The Working Group Report, NITI Aayog, 2018; https://niti.gov.in/sites/default/files/2019-07/ WG-Report-issued-for-printing.pdf

8. Srivastava, S. K., Mathur, V. C., Sivaramane, N., Kumar, R., Hasan, R. and Meena, P. C., Unravelling food basket of Indian households: revisiting underlying changes and future food demand. Indian J. Agric. Econ., 2013, 68(4), 535-551.

9. Birthal, P. S., Joshi, P. K., Roy, D. and Thorat, A., Diversification in Indian agriculture towards high-value crops: the role of small- holders. IFPRI Discussion Paper 00727, International Food Policy Research Institute, Washington, DC, USA, 2007.

10. Chand, R. and Srivastava, S. K., Agriculture performance in India: main trends, commercialisation and regional disparities. In Rural India Perspective 2017 (eds Roy, D., Nair, G. and Mani, G.), National Bank for Agriculture and Rural Development, Mumbai, 2018, pp. 1-15.

11. GoI, Report of the Committee on Doubling Farmers' Income: input management for resource use efficiency and total factor productivity, volume VII. Department of Agriculture, Cooperation and Farmers' Welfare, Ministry of Agriculture and Farmers' Welfare, Government of India, 2018; http://agricoop.gov.in/sites/ default/files/DFI\%20Volume\%207.pdf

12. Srivastava, S. K., Chand, R. and Singh, J., Changing crop production cost in India: input prices, substitution and technological effects. Agric. Econ. Res. Rev. (Conference Issue), 2017, 30, 171182.

13. Chand, R., New farm Acts: understanding the implications. NITI Working Paper Series 1/2020, NITI Aayog, 2020; https://niti.gov. in/sites/default/files/2020-11/New_Farm_Acts_2020.pdf

14. Srivastava, S. K., Singh, J., Kumar, N. R., Singh, N. P. and Ahmad, N., Changing agricultural labour market and its effects on farm economy in India. Indian J. Agric. Econ., 2020, 75(4), 469480 .

15. Rao, N. C. and Dasgupta, S., Nature and employment in the food processing sector. Econ. Polit. Wkly, 2009, 44(17), 109-115.

Received 19 February 2021; accepted 2 March 2021

doi: $10.18520 / \mathrm{cs} / \mathrm{v} 120 / \mathrm{i} 6 / 981-988$ 